\title{
Between Necessity and Delight Negotiating Involved Fatherhood among Career Couples in Denmark
}

\author{
By ANNA SOFIE BACH
}

\begin{abstract}
Between Necessity and Delight. Negotiating Involved Fatherhood among Career Couples in Denmark Fathering practices are changing. Many fathers are no longer simply providers but are also active caregivers. While women's entry into the labour market spurred a need for men to engage with the 'second shift', research has showed that men's engagement with childcare does not necessarily imply an equal division of labour. By examining the construction of father's identity in a context where traditional scripts for 'doing family' cannot (easily) be applied, this article discusses how necessity affects practices of involved fathering and the sharing of responsibilities. Based on qualitative interviews with 22 Danish men who are in relationships with so-called career women, the article argues that among this group of men, who in many ways appear as frontrunners of egalitarian family practices, fathers' involvement is not only negotiated as a an emotional investment but also from a need to 'make it work'. These fathers' close relationships with their children and their parental independency is as much the result of the career orientation of the mothers as an expression of their having embraced the (Nordic) ideal of gender-neutral, symmetrical parenthood. Finally, in showing how intensive involvement and care-giving change men's experience of fatherhood, the article contributes to the ongoing academic enquiry into what it means to be an involved father.
\end{abstract}

\section{KEYWORDS}

Fatherhood, gender equality, masculinity, family practices

Anna Sofie Bach is a PhD student in the Department of Sociology at University of Copenhagen. Her research explores continuity and change in heterosexual family and relationship practices focusing in particular on the construction of masculine identity among men who are partnering women with career jobs. 


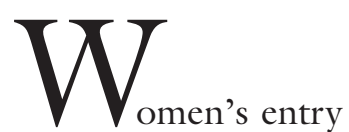

into the labour market and their increasing presence in the educational system have prompted an ongoing reorganization of gendered relations of domestic and intimate life. As recently as the 1950s and 60s, sociologists described the (Western) family as an institution wherein men and women performed specific and distinct roles. Fathers were seen as breadwinners and as the family's connection to the outside world, while nurturing and care-giving were the mother's prerogative (Parsons and Bales 1955). Today, men are increasingly involved in nurturing and raising their children, especially in the Nordic countries where men's parental involvement has received political support for several decades. These new fathering practices, which are broadly recognized by social scientists as involved fatherhood, have engaged scholars all over the world in an ongoing discussion of what it means to be an involved father, and of whether and how men's involvement with children is connected to transformations of the structure of family life.

The present article discusses how changing social structures affect men's fathering practices, illuminating the extent to which the increased involvement of fathers results as much from changing circumstances of family life as from changing ideals. In particular, the article broaches the discussion about how women's career orientation affects fatherhood practices (e.g. Björk 2013, Chronholm 2004). By examining the stories of a group of Danish men who practise involved fatherhood in a dualearner/career context, where traditional script for doing family and gender cannot (easily) be applied, the article describes how such men negotiate domestic responsibility and construct fathers' identities as care-givers. While the men in this study in many ways exemplify involved fatherhood, their stories also reveal that force of circumstance has influenced their involvement in care-giving as much as (the Nordic) ideals of involved fatherhood and gender equality. As men's engagement with children has been assumed to be one way to increase equality both within the household and in the labour market, the scholarly interest in the so-called 'new fathers' is closely connected to discussions of gender equality. However, numerous studies have showed that men's family orientation and involvement do not necessarily imply equal sharing of household responsibilities. The article also discusses how men's intensive involvement in their children's care affects the gendered structures of family practices, and whether it also transforms manhood. That is, love and nurturing practices have been advanced as important elements in the attempt to displace patriarchal power structures. Such practices are seen as central components in a restructuration of masculinity, that is a reconstruction of men's emotional lives that changes what it means to be a man (e.g. hooks 2005).

The article starts out by outlining the theoretical framework and introducing the empirical study. The analysis falls in three parts. Part one illuminates the circumstances that prompt these men to be involved in primary care-giving and discusses how their practices are embedded in contemporary Nordic discourses on family and involved fatherhood. The article goes on to describe how the regular absence of the mother affects fathering practices, illuminating how time spend alone with children is important in relation to how these men construct themselves as fathers. Finally, the article takes up the discussion of how the practice of care-giving changes what it means to be a father - and hence, a man. 


\section{THEORETICAL FRAMEWORK}

The analysis takes as its starting point a practice-theoretical understanding of family and parenthood informed by David Morgan's notion of family practices and Judith Butler's concept of gender performativity. Privileging neither intention nor discourses, a practice-theoretical approach provides a distinct analytical view of everyday life by focusing on social action and practices as performativity (Halkier and Jensen 2008). In his work, Morgan argues for an understanding of families in which family members are constituted through their everyday practices in relation to each other rather than as solid and static units (Morgan 2011). The examination of the 'doing of family' rather than 'The Family' as an institution provides the researcher with a better point of departure for the observation of variations between families and of nuances inherent to social change. Additionally, a practice-theoretical approach implies that practices should be understood as being organized around a shared (practical) understanding of how 'we' do (Schatzki, Knorr-Cetina, and Savigny 2001:12). That is, social meaning is ascribed to practices, establishing hierarchies and dichotomies that produce and reproduce cultural norms and regulation. For instance, we cannot ignore how men as fathers are constructed in relation to women as mothers, since the doing of family is inextricable from the 'doing of gender' (Morgan 2011).

Contemporary parental practices are connected to historically constructed scripts for motherhood and fatherhood that have close links to the institutionalization of what Butler has called the heteronormative matrix, that is, gendered structures founded in a binary understanding of gender as the effect of biological bodies (Butler 2006). As industrialization in the West during the $18^{\text {th }}$ century separated work from home, 'woman' was constructed as 'mother', as caregiver and home-maker, and 'man' as 'breadwinner'. This family model institutionalized the scientific gender essentialism of the $18^{\text {th }}$ and $19^{\text {th }}$ century, which perceived men and women as fundamentally different, due to their biological relations to reproduction (Rosenbeck 1990). Using Butler's theory of gender performativity (Butler 2006), my analysis departs from an understanding of gender as a 'doing', through which male and female bodies are constituted as men and women as well as mothers and fathers through the discourses of what it means to be a man, a woman, a mother, a father and a care-giver. Even though the male breadwinner family model has only been valid for certain social groups and over a short period of history, its persistence as a cultural reference still shapes our notions of family and our expectations towards family life, sustaining semiessentialist beliefs of what comes 'naturally' to mothers and fathers (Björk 2013, Holter 2007b, Kaufman 2013).

For decades, working women have struggled with what Arlie Hochschild termed 'the second shift', that is, taking care of children and households alongside paid work (Hochschild and Machung 1989). In Denmark, however, the latest time study shows that men are participating much more actively in housework. The gender gap has reduced from four hours in 1964 to 48 minutes in 2009 (Bonke and Jensen 2012).1 While this indicates that Danish women no longer face the second shift alone, studies also show that housework is still distinctively gendered (Bonke and Jensen 2012:76, Forsberg 2007, Magnusson 2006).

However, the biggest labour redistribution seems to have happened in relation to childcare. Today, Danish fathers spend almost as much time with their children as mothers do and participate much more in care-giving activities (Bonke and EspingAndersen 2011). In the Nordic countries in particular, where men's care-giving has been politically supported since the 1980s 
through parental leave and social benefits, researchers claim that what has been termed involved fatherhood has become the predominant ideal, changing what it means to be a father (Aarseth 2009, Forsberg 2009, Holter 2007a, Lorentzen 2012, Olsen 2007). In Sweden, scholars have even suggested that involved fatherhood has become incorporated into hegemonic masculinity and has changed what it means to be a man. Disputing this, others have emphasized that fathers' involvement with children does not necessarily disturb the overall division of labour in the family, or change the gendered inequalities of the labour market (Hearn et al. 2012). Hence, several studies have demonstrated that men's child-orientation does not necessarily imply either gender-equal division of labour nor symmetrical parenthood (Bekkengen 2002, Bonke and Jensen 2012, Magnusson 2006, Roman and Peterson 2011). As a result, scholars debate what it actually means to be 'involved'. Since most fathers have always been emotionally engaged in their children (Lorentzen 2012), Monica Rudberg and Harriet Bjerrum Nielsen have suggested that the 'new' in contemporary involved fatherhood is the affective investment of fathers in the 'nitty-gritty' of everyday life and their desire to be 'hands-on dads' who engage in the basics of caring for children (Rudberg and Bjerrum Nielsen 2012:56-57). Sociologist Gayle Kaufman finds that one way of distinguishing this new desire for involvement from the wish of former generations of fathers 'to be there' for their children is by looking at the relationship between paid work and family time in men's stories (Kaufman 2013). In Kaufman's opinion, the 'new fathers' and 'superdads' can be determined by their willingness to adapt their work life, in order to make time to engage in primary care-giving.

\section{Producing NARRATIVES OF INVOLVED FATHERHOOD}

The analysis is based on 22 in-depth interviews conducted in 2012-2013 with Danish men between the ages of 30-50 as part of my $\mathrm{PhD}$ dissertation research, in which I explored men's experiences of living with so-called 'career women'. The men were recruited on the basis of having a partner whose job situation applied to a broad definition of 'career', which, in this study, is operationally defined by three criteria that must be assumed to affect both everyday life and the social power and status of the woman: high income, long weekly working hours and management responsibilities. ${ }^{2}$ In most cases, the woman meets all three criteria. Because the couples were selected by the wife's occupation, the men's relationship with the labour market varied widely: at one end, is a man staying at home being provided for by his wife, while at the other end, is an executive director, who has a greater responsibility and makes more money than his wife. The overall tendency in the material is, however, towards less conventional couples, in which the women have higher positions, higher salaries and longer working hours than their husbands. Aside from this, the couples can be characterized as belonging to an educated, urban upper middle-class. They are all homeowners in good neighbourhoods, and the majority of them have annual household incomes around or above 1. million DKK (roughly 200,000 USD - placing them among in the upper $12 \%$ of Danish couples (Statistics Denmark 2013)). Out of the 22 interviewees, 19 had children and one couple was expecting their first child. 10 of the couples had two children, while six had three children. Only three couples had one child and they were all discussing the option of having more. Of the couples, 16 had children under the age of six.

Taking Cathrine Riessman's narrative approach as a basis, I have worked with the stories produced in the interviews as social 
artefacts, from which we learn not only about the person who is telling the story but also about the society and the culture in which the story is told (Riessman 2008). Storytelling produces and reproduces both personal and cultural narratives, but since not all talk is narrative, a fundamental criterion for narratives is the production of contingency, in other words, the consequential linking of events or ideas. That is, narratives are produced in processes of meaningmaking. Riessman finds that stories are performative in the sense that storytelling is social interaction and closely connected to the production of identity. Or, as Nira Yuval-Davis says, identities are narratives, stories that people tell themselves and others about who they are (and who they are not) (Yuval-Davis 2007). As stories in this sense must be regarded as composed and received in context, Riessman suggests a dialogic/performative analysis that extends beyond the content of the story (Riessman 2008). She advocates not only that we include how stories are told in our analysis, but also that we address to whom they are told and how this context co-produces the narrative. Stories are always intended for an audience, which might not be limited only to the researcher present during the interview (Riessman 2008:211213). This analytical strategy implies that I have worked with the stories of fathering practices, focusing on how the men construct their 'father' identity through the production and reproduction of different narratives that form the way they see themselves as well as how they want to be seen as fathers and as men - by me, whom they were talking to, by their partner who might read my work, and by society in general.

\section{FAMILY AND CAREER - CHOOSING TO BE AN INVOLVED FATHER}

When I first prepared my interview guide for my project, fathering was a topic on my list since I am interested in how changing power relations affect family practices. I was, however, struck by how much space fatherhood took up in the interviews. Actually, it was often hard to separate the stories of being a couple from the stories of being parents. That is, having children was 'storied' as a life-and-relationship-changing event by most of the men. Not only because becoming a parent contains a lot of symbolic meanings, especially to the middle-class (Plantin 2007), but because having a child simply brought fundamental changes to the everyday life of these men. With the birth of their first child, all of these men were introduced to an extensive set of new activities, generating a different level of time pressure in their everyday life and facilitating a new world of emotional satisfaction. Despite the fact that only a few of them made radical changes to their working lives, which is Kaufman's way of distinguishing between what she calls 'new dads' and 'superdads', these men all stand out as highly involved fathers.

In an initial choice that demonstrated their involvement, all of them took parental leave in relation to the birth, and the majority subsequently also stayed at home for 3-4 months of paternity leave. Taking such leave already marked them as significantly more involved in primary childcare than most Danish fathers, who only take approx. $9 \%$ of the days eligible to be spent on leave (Lammi-Taskula et al. 2012). ${ }^{3}$ In the stories, the majority of the men explained that their decision to take long periods of leave derived in part from a wish to spend time with their child, and in part from the mother's wish not to stay home for a whole year, which is the period of time reimbursed on average by parental leave regulations in Denmark. On the other hand, the men's desire to stay at home with a baby showed to be moderate, as none of my interviewees' leave exceeded the leave of their partner, even though more than one man revealed that he had been offered more or even all of the leave. 
On an everyday level, most of the men had made adjustments to their work lives that enabled them to drop off and pick up children from day-care, bring home work in order to pick up their children early and work from home when their children were sick. It is significant when trying to understand how women's career orientation affects men's fathering practices that a number of the men claimed to have adjusted their own career ambitions in order for their wife to be able to pursue her dreams. Kristoffer, who considered himself less ambitious than his wife, had been working part-time for some years in a job that did not match his educational level. He said about this decision:

"I have been able to... justify to myself that I worked there because it made sense when Katrine was struggling every day to get home and to pick up the children. I mean, in that sense it was a brilliant job, really. So it has definitely been something we calculated that she was the one who got more space and it was me who took...who ran this [the home].

Otherwise she wouldn't have been able to work like this. It was a choice we made." (Kristoffer)

Even though much of the conversation with Kristoffer actually focused on his frustrations with being in charge of 'the second shift', he devoted a lot of energy to the composition of a story in which he is an active agent who is part of the decisionmaking. They chose this family arrangement. He chose to compromise on his own job in order to have their family life meet his standards of quality: home-cooked food, fun activities for the children, who should not stay too long in day-care, etc. The close relationship with his children depicted in his story is also very important, giving meaning to the narrative constructed through choosing to be the primary caregiver, while his wife works 60-70 hours most weeks.

In her study of Swedish fathers who work part-time, Sofia Björk also finds a strong discourse of choice. She argues that the involvement-as-choice discourse can be seen as a demonstration of hegemonic masculinity, as men are expected to explain themselves in terms of active choice (Björk 2013:229). If so, Kristoffer negotiates necessity into choice, hereby restoring himself as a culturally intelligible man, one who demonstrates decisiveness and self-determination despite the fact that he ended up as the home-maker. According to Björk, the discourse of involvement-as-choice is part of a middleclass discourse of reflexivity, underlining the construction of fatherhood as a project rather than something that just happened to them (Björk 2013:230, see also e.g. Aarseth 2009; Plantin 2007). This discourse might be particularly prevalent in my interviews, as the men in general try hard not to be positioned as henpecked, as 'losers' in a (symbolic) struggle of marital power and status. Yet, this reflexivity also derives, at least in part, from the career orientation of the women, which challenges a more traditional positioning of the mother as the primary caregiver. The majority of the interviews convey underlying stories of the division of labour as an ongoing conversational topic between the couples. In fact, several of the men reported that their partners established from the beginning that they would not automatically scale down their ambitions just because they were to become mothers; rather, they expected their husbands to contribute to the household. For instance, Rene explained that his partner took up the topic of shared responsibilities even before she became pregnant:

"She said that, like, if we are having children it has to be a shared project. It has to be a joint effort. We talked about that, you know. She was like, 'don't expect me to be home and take care of the child while you are at work. It's not going to be like that.' That was clear from the beginning." (Rene) 
As the account shows, the women generally seem aware that their ability to pursue a career requires male commitment to the family project. Like many of the men, Rene admitted that things would in some ways have been easier for him had he had a partner who had wanted to be the homemaker. From the stories we learn that a willingness to compromise on your own work-related ambitions in order to be able to share the responsibilities at home is part of the deal when choosing to be with an ambitious woman.

Summing up, the stories indicate that, unlike in former generations, these men acknowledge a domestic responsibility, especially when forming a family with a career-oriented woman. They are willing to commit more or less to homemaking and want to take part in the care-giving which is given meaning through emotional relations with children and the narrative of family as a joint project. In the next section I take a closer look at how male involvement is also embedded in a narrative of necessity that constructs their commitment as part of struggle to 'make it work'.

\section{CHOOSING TO START A FAMILY - MAKING IT WORK}

While several studies have showed equal sharing to be an ideal among couples in the Nordic countries, they also point to a discrepancy between ideals and the practical reality of family life (e.g. Forsberg 2007, Magnusson 2006; Roman and Peterson 2011). With a few exceptions, the men's narratives in this study show them sharing responsibilities fairly equally with their partners. Because they plan their everyday sharing in detail, the majority of the men are able to tell exactly who does what and when. For instance, these couples all share calendar systems in which they for instance arrange months ahead who is to drop off and pick up children, and they coordinate activities so they will not have conflicting appointments. Even though equal sharing is part of the narrative constructed in the stories of dividing domestic labour, most of the men reject the idea of 50-50 models in favour of a 'make-it-work' storyline. On the one hand, their preference for this wording could be seen as them practising gender equality by naturalizing sharing as the way to 'make-it-work'. On the other hand, this wording also derives from a narrative of necessity; if the man does not participate, the ends will simply not meet unless they request intensive assistance of external help from domestic services.

Many of these financially privileged families actually do 'make it work' by enlisting paid services that relieve them of household responsibilities, including cleaning, gardening and cooking. For instance, David and his wife buy take-away meals when their schedule is extremely tight, and this occurs on a weekly basis. Although the majority of the couples avail themselves of paid housekeeping, none makes use of regular paid childcare over and above the public daycare system. Even though several of the couples could afford to hire an au pair, and some have discussed it, it becomes clear from the stories that these men (and women) designate childcare as pleasurable, desirable and having a value that is different to other types of housework that they outsource.

Evidently, involved fatherhood is constructed by the fathers as being physically present to spend (quality) time with children. For instance, Anders said, "I couldn't imagine having someone else take care of my children because I didn't have time to do it myself. This was not why I had children.". Meanwhile, Anders actually revealed during the interview that his mother-in-law picks up the children once or twice a week from day-care, because lack of time is sometimes an issue. Indeed, grandparental assistance functions as an indispensable part of 'making it work' in several of these dual-earner couples, though 
to a lesser degree than in, for instance, China, where a grandmother often moves in with the young couple to take care of children and housekeeping (Yifei 2011).

Regardless of the actual help they may receive, these fathers value the ability to pick up their children themselves and to spend the afternoons sharing some kind of 'quality time' playing with their children. In their stories, this is constructed as a reward of choosing to be an involved father who engages in the everyday family work. Notably, however, such 'quality time' may be the privilege of the well-educated upper middle-class, who also prioritize spending time with their children more than other social groups (e.g. Bonke and EspingAndersen 2011). Importantly, the ability to prioritize is socially differentiated. Flexible jobs, for instance, that allow the employee to leave early and work from home after putting the children to bed remain the privilege (and perhaps also the downside) of well-educated people in the 'knowledge industries'. Similarly, only those with financial latitude can buy time-saving services. However, in their stories, the interviewees' ability to prioritize time at home is not as such seen as a privilege but is presented as a choice: family is chosen over work. For instance, Søren, who actually has a very time consuming job, says more than once: "I would never prioritize a job that meant that I didn't have time for the kids". This feeds into the narrative constructed in most of the interviews that family is an active choice and something into which a father therefore must invest emotional effort as well as time. Even though having children is also regarded as a 'natural' extension of well-functioning couplehood, establishing a family is conveyed as a choice. And this is a choice that is adapted to the overall life projects of both parents, a storyline that has also previously been found to be a cultural narrative of the middle-class in the Nordic countries (Aarseth 2009, Roman and Peterson 2011).
My study demonstrates how the narratives of involved fatherhood among this group of men are built into an overall construction of parenthood as choice, in which their willingness to comply with necessity and share childcare responsibilities with mothers who are not prepared to perform the role of home-makers also plays an important role. However, what is particularly interesting in the stories, is how the fathers' close relationships with their children, developed through intensive involvement, are posted not as the motive of involvement, but as a positive 'sideeffect' of being married to a busy and at times distant woman, whose ambitions make the father's care-giving necessary. In the next section, I discuss how this insight informs the notion of involved fathering.

\section{"ON THE POSITIVE SIDE I GET TO SPEND MORE TIME AS A DAD"}

Most of the men in my study are married to women whose jobs require long weekly hours at work and frequent travelling. In some cases, travelling is even a weekly occurrence that on a regular basis leaves the father with all responsibilities for the children. For none of the men does this seem unreasonable, though it is sometimes exhausting, and on such days they have adjusted their own work schedules in order to be able to take on the full 'second shift'.

One such man is Bo, whose wife is the busy administrative director of a large company. When asked for an estimate of her weekly hours, he did not venture a guess, explaining, "I really don't know. She works when I go to bed and when I wake up, she is working in the bed next to me". For a couple of years she has spent one or two days a week away from the family. Taking on the full responsibility for the care of the children on his own did not seem to represent an insuperable task to Bo. He laughingly relayed an incident when he met a male acquaintance in the supermarket who 
was completely stressed out by the fact that his wife had an overnight stay at a seminar, leaving him to take care of the children all by himself. Bo's friendly ridicule sets him apart from this man, who is not used to, and therefore not able to, take care of his children on his own. Significantly, Bo could not understand why the other man did not regard the situation as an opportunity to spend some time alone with his children, to paraphrase Bo's words. This account is interesting, since Bo was one of the few men in my study not to draw very actively on the discourse of involved fatherhood as a choice - and hence, as an ideal. He did, however, voice very actively his delight in spending time with his children. He talked significantly more about all the things he does with his children than about what he does with his wife or what they do as a family, underlining the fact that he spends a lot of time alone with the children. When asked what he thought would have been different if his wife had not worked this much, he said that he would probably not have known his children as well as he does, because his wife would have been in charge of the childcare. When she is home, Bo revealed, his wife takes over most of the care for the children. It is clear from Bo's story that he prioritizes his children and finds pleasure in spending time with them. However, Bo is not an involved father because he believes strongly in symmetrical parenthood or the value of male caregiving; rather, he has become a so-called 'new father' through force of circumstance.

Circumstantial necessity also plays a part in the stories of men who are constructing narratives that draw much more actively upon the ideal of involved fatherhood. Exemplifying this, circumstance plays a very central part in the way Anders develops his narrative about being an involved father. In contrast to Bo, Anders works hard during the interview to construct himself as the type of father Kaufman considers a 'superdad'. For instance, family is such a high pri- ority in his life that he claims to have given up his career job as a consultant and started his own business in order to have more time at home. When his wife was later offered a management position, he supported her completely, even though it requires weekly travelling and management responsibilities, giving Anders by 'default' (his words) a lot of the childcare responsibilities. According to Anders' story, his wife invests effort in preventing her career ambitions taking time away from their family life. However, as with Bo, in Anders' narrative the time he spends alone with his children is presented as a positive aspect of his wife's job and ambitions. When explaining the negative effects of her job, such as her time away from the family, he adds:

"Then on the positive side I get much more time as a dad with my children. Because women are just so damn good at entering the room where the kids are and then just taking over everything. And good at multi-tasking and things like that...that, I must say, is not a story women have invented. I mean, you women are just better at that, right. For me, her absence means that I have had the opportunity to put much more efforts into being a dad. And that's something I am actually grateful for. I mean, that Anne is away and sometimes a long way away." (Bo)

What is important in the stories of both Anders and Bo is that they both present spending time alone with their children as a means to develop strong bonds with them. In this way my material exemplifies an observation made by Adrienne Burgess, who argues that even though fathers spend more time with their children than ever before, a lot of this time is still mediated by the presence of the mother, making it harder to develop the potential of their involvement (Burgess (1997) in Craig 2007). Such maternal mediation comes about in part through the cultural story of the 'naturalness' of female care-giving, 
which we also see echoed in the quote above - and which is given an extra edge when Anders includes me as a female researcher in his categorization. Further, the quote shows how Anders feels that his relationship with his children requires effort, while the mother-child relationship is constructed as more natural and resilient, even when the mother is actually absent more often in this family than he is. It is significant that, even though gendered differences are upheld in the above stories, the time and the effort Anders, Bo, and the other men invest in fathering have the potential to challenge and change such beliefs in the 'natural' gendered differences between mothers and fathers, as I will show in the following section.

\section{INVOLVED FATHERS AS}

\section{COMPETENT AND INDEPENDENT}

Not only does time spent alone with the children enhance the emotional relationship between father and child, it also facilitates the development of more symmetrical and equal parental practices. For instance, another interviewee, David, described how spending six months on paternity leave with their youngest child has made the parental relation more equal, as he now regards himself as a much more independent and able care-giver. He said:

"It gave me a lot, you know... as regards my identity. I mean, in relation to this child, we are equals, not only in decision-making, but also when it comes to, let's say a thing like when we have to go somewhere and you need to bring some stuff for your kid. It was always my wife who did that with our big girl, because she knew exactly what to pack and then it was better she was the one to do it. Now I feel that I know that, too, I know what's important to remember. Like for instance to bring four diapers, if you are to be out all day. And you need some wipes and there needs to be extra clothes if anything gets spilled. [...] It's obvious that, having been on paternity leave, I'm familiar with doing this. Before, I could do it, but I would need to be told what to put in the bag. Then she could just as well do it herself. Instead of telling me, and then I, I mean, that would be unnecessary duplication. Being on leave with a child has given me a sense of how we get on with everyday life. I have become much more independent as a parent." (David)

In the quote, David's construction of father identity centres around his appropriation of practical skills through the practice of care-giving. His story demonstrates how spending time with the child is an important part of developing parental skills and hereby identity. By practising involved fatherhood, he becomes a competent caregiver who is able to anticipate the needs of his child. Significantly, by being on paternity leave for a long period of time, David's bond with his child becomes unmediated by the mother as care-giver. His involvement also changes the relationship between the parents, since he is able to construct himself as equal to the mother due to his mastery of care-giving. Not only does his independence relieve his wife from the burden of double work, it also facilitates a feeling in David of not being second-best in the child's life. For instance, he explains that his child is comforted equally whether by him or his wife, and that he cannot see why his wife travelling a lot should pose a problem, as friends and family sometimes maintain. The child is being cared for equally well by him. Through his involvement, then, David is able to dismiss the gendered difference between mother and father, creating room for the actual practice of symmetrical parenthood. This goes to show that men's parental leave cannot be regarded as an isolated expression of an ideal of involvement. Rather it is an important piece in facilitating a real transformation of the father from being involved to becoming an equal and equally competent care-giver. 


\section{Conclusion}

This article has discussed how men who are partners of women with career jobs practise involved fatherhood. The analysis shows how women's career orientation stimulates a very concrete need for the men to be involved unless the couple hires someone to relieve them from 'the second shift'. The article argues that a need to 'make it work' is as much a driving force in sharing childcare and household responsibilities as the strong Scandinavian ideal of involved fatherhood. In saying this, I am not implying that these men's involvement is not about valuing close and emotionally strong bonds with their children or that they do not believe in symmetrical parenthood. My errand in this article is in no way to discredit these men, who on an individual level all do commendable jobs as careful fathers and supportive partners of ambitious women. My point is that it can be easy to overlook how the structural necessity of male care-giving seems to be as important in the transformation of men's parental practices as cultural ideals of involved fatherhood. In these 'extreme' cases, it becomes clear that the actual sharing of responsibilities is fuelled as much by living with a career-orientated woman as by a latent willingness to participate, which is a component in both the ideal of involved fatherhood and the middle-class discourse of family-as-choice. It is through the practice of care-giving, I found, that these men become competent and confident caregivers. And furthermore, that it is this practice that provides the foundation for breaking down the cultural narrative of mothers as natural caregivers and for constructing men as equally competent care-givers. While the extent of their care-giving through a statistical lens might appear unconventional, the men become culturally intelligible as fathers within the discourse of intensive parenting. However, this study also demonstrates how even these men's involvement and work-related adjustments are articulated in their narratives in terms of choice, which can be seen as a way for the men to assert themselves as self-determined male subjects in stories of intensive home-making, that is, stories that to some extent still challenge the cultural stories of men's 'natural' preferences.

This study reveals the subversive potential in men's care-giving, even when the involvement is driven by necessity. According to Stevi Jackson, numerous studies have suggested that caring is integral to how women practise love, and that it is love that makes domestic work meaningful to women (Jackson 2014). When love of children is the reason for men to engage in the labour of 'making it work', domestic work can become meaningful to them in another way than as the abstract practice of striving for fairness oriented around equality. If that is so, it is reasonable to assume that men's intensive involvement in childcare might actually hold a key to adjusting the division of labour by dissolving the cultural narratives of gendered difference through the practice of symmetrical parenthood. The findings of this study suggest that fathers should spend more time alone with their children. When men stay at home with younger children, for instance on paternity leave, there are positive effects that reach beyond the individual fatherchild relationship that is developed. Consequently, social systems that support men's care-giving are important, in order to support symmetrical parenthood that relieves women of the burden of the 'second shift'. Whatever their adherence to equality in principle, some men might need a friendly 'nudge' into the practice of care-giving. Since not all women are going to pursue time-consuming career jobs, this could be facilitated through institutionalizing paternity leave, for instance through 'daddy' quotas. 


\section{Notes}

1. Bonke \& Esping-Andersen (2011) call this a 'lagged adaptation' as the decreasing difference is as much a result of a decrease in women's time spent on housework as an increase in men's.

2. The woman had to live up to a least one of the following characteristics: management responsibilities; earns more than 500,000 DKR. per year before taxes; work considerably more than 37 hours a week.

3. More recent figures from Statistics Denmark show that fathers' share of leave seems to be increasing. In 2012, in couples where both parents took leave, the men accounted for $12 \%$ of the days spend at home with the child (Statistics Denmark 2014). In Denmark, employed parents have the right to 52 weeks of parental leave on full leave benefit (which does not mean a full salary to most people). The father has the right to two weeks of paternity leave within the first 14 weeks of the child's life. Thirty-two weeks (the parental leave) of the 52 can be shared between the parents. Through labour market agreements, some Danish women and men are entitled to 3-6 months of paid leave in which they will be fully financially reimbursed.

\section{LITERATURE}

- Aarseth, Helene (2009): "From Modernized Masculinity to Degendered Lifestyle Projects Changes in Men's Narratives on Domestic Participation 1990-2005." Men and Masculinities 11(4):424-40.

- Bekkengen, Lisbeth (2002): Man fär välja - om föräldraskap och föräldraledighet $i$ arbetsliv och familjeliv. Dissertation, Karlstad University.

- Björk, Sofia (2013): "Doing Morally Intelligible Fatherhood: Swedish Fathers' Accounts of Their Parental Part-Time Work Choices." Fathering: A Journal of Theory, Research, and Practice about Men as Fathers 11(2):221-37.

- Bonke, Jens and Gøsta Esping-Andersen (2011): "Family Investments in Children-Productivities, Preferences, and Parental Child Care." European Sociological Review 27(1):43-55.

- Bonke, Jens and Bent Jensen (2012): Har vi tid til velfard?: om danskernes brug af deres tid ude og hjemme. Gyldendal, København.

- Butler, Judith (2006): Gender Trouble, Feminism and the Subversion of Identity. [Reprint.].

Routledge, New York.
- Chronholm, Anders (2004): Foraldraledig pappa: mans erfarenheter av delad foraldraledighet. Goteborg, Goteborg University.

. Craig, L. (2007): "Does Father Care Mean Fathers Share? A Comparison of How Mothers and Fathers in Intact Families Spend Time with Children." SAGE Family Studies Abstracts 29(1).

· Forsberg, Lucas (2007): "Negotiating Involved Fatherhood : Household Work, Childcare and Spending Time with Children." Norma 2:2, s. 109-126..

- Forsberg, Lucas (2009): Involved Parenthood: Everyday Lives of Swedish Middle-Class Families. Dissertation, Mälardalen University.

- Halkier, B. and I. Jensen (2008): "Det Sociale Som Performativitet-et Praksisteoretisk Perspektiv Plaa Analyse Og Metode." Dansk Sociologi 19(3):49-68.

. Hearn, Jeff et al. (2012): "Hegemonic Masculinity and Beyond 40 Years of Research in Sweden." Men and Masculinities 15(1):31-55.

- Hochschild, Arlie Russell and Anne Machung. (1989): The Second Shift: Working Parents and the Revolution at Home. Viking, New York, N.Y.

- Holter, Øystein Gullvåg (2007a): Män i rörelse: jämställdhet, förändring och social innovation $i$ Norden. Gidlund, Stockholm.

· Holter, Øystein Gullvåg (2007b): “Men's Work and Family Reconciliation in Europe." Men and Masculinities 9(4):425-56.

- hooks, bell (2005): The Will to Change: Men, Masculinity, and Love. Simon \& Schuster, New York; London.

- Jackson, Stevi (2014): "Love, Social Change and Everyday Heterosexuality." in Anna G. Jónasdóttir and Ann Ferguson (ed.): Love. A Question for Feminism in the Twenty-First Century. Routledge, New York.

- Kaufman, Gayle (2013): Superdads: How Fathers Balance Work and Family in the 21st Century.

NYU Press, New York.

- Lammi-Taskula, Johanna et al. (2012): Publikation: Parental Leave, Childcare and Gender Equality in the Nordic Countries. Nordic Council of Ministers.

- Lorentzen, Jørgen (2012): Fra farskapets historie $i$ Norge: 1850-2011. Oslo: Universitetsforlag - Magnusson, Eva (2006): Hon, Han Och Hemmet: Genuspsykologiska Perspektiv På Vardagslivet I Nordiska Barnfamiljer. Natur och Kultur, Stockholm.

- Morgan, David H. J. (2011): Rethinking Family Practices. Palgrave Macmillan, Basingstoke. . Olsen, Bente Marianne (2007): “Tid Til Omsorg, Tid Til Forandring? Familie Og Arbejdsliv 
Hos En Gruppe Danske Småbørnsfædre .” in Øystein Gullvag Holter (ed.): Män i rörelse. Jämställdhet, förändring och social innovation $i$ Norden. Gidlunds Förlag.

- Parsons, Talcott and Robert Freed Bales (1955): Family, Socialization and Interaction Process,. Free Press, Glencoe, Ill.

- Plantin, Lars (2007): "Different Classes, Different Fathers?" Community, Work Eramp; Family 10(1):93-110.

- Riessman, Catherine Kohler (2008): Narrative Methods for the Human Sciences. SAGE Publications, Inc.

- Roman, Christine and Helen Peterson (2011):

Familjer I Tiden: Förhandling, Kön Och Gränslöst Arbete. Borea, Umeå.

- Rosenbeck, Bente (1990): Kvindekøn. Den

Moderne Kvindeligheds Historie 1880-1980.

Gyldendal, Kbh.

- Rudberg, Monica and Harriet Bjerrum Nielsen
(2012): “The Making of a 'new Man': Psychosocial Change in a Generational Context." Journal of Psycho-Social Studies 6(1).

-Schatzki, Theodore R., K. Knorr-Cetina, and Eike von Savigny (2001): The Practice Turn in Contemporary Theory. Routledge, London; New York.

- Statistics Denmark (2013): Indkomster 2011. Danmarks statistik.

- Statistics Denmark (2014): "Nyt Fra Danmarks Statistik: Fædre Er Igen Begyndt at Holde Mere Barsel." Danmarks Statistik.

- Yifei, Shen (2011): "China in the 'PostPatriarchal Era." Chinese Sociology \& Anthropology 43(4):5-23.

- Yuval-Davis, Nira (2007): "Identity, Identity Politics and the Constructionism Debate." Localized at http://www.uel.ac.uk/ipsa/documents/bsa2.pdf. 